(C) М.А. Канзюба, Д.Ю. Ковальчук, А.І. Канзюба, 2020

УДК 616.718.42-001.5-089.166-053.7

\title{
Хірургічна тактика при переломах шийки стегнової кістки у осіб молодого віку
}

\author{
А.І. Канзюба, М.А. Канзюба, Д.Ю. Ковальчук \\ ${ }^{1}$ Ужгородський начіональний університет, Ужггород; \\ ${ }^{2}$ Донецький національний медичний університет, Лиман; \\ ${ }^{3}$ Національний медичний університет ім. О.О. Богомольия, Київ
}

\section{Реферат}

У віці до 60 років переломи шийки стегнової кістки (ПШСК) складають від 2 до 6\% від усіх переломів у ділянці кульшового суглоба i, в більшості випадків, є наслідком високоенергетичного впливу. Пріоритетним напрямком оптимізації хірургічної тактики є вдосконалення остеосинтезу на підставі клінічних та біомеханічних досліджень, присвячених вибору конструкції фіксаторів та обгрунтуванню параметрів їх введення в проксимальний відділ стегнової кістки. Представлено аналіз застосування внутрішнього остеосинтезу при ПШСК в період з 2013 по 2019 рр. у 42 пацієнтів віком від 18 до 58 років (середній вік - 42,3 $\pm 1,1$ року). Вибір конструкції та параметри остеосинтезу визначені на основі результатів моделювання напружено деформованого стану (НДС) проксимального відділу стегнової кістки. У терміни від 3,5 до 6 років у 34 пацієнтів вивчені результати лікування по Harris Hip Score: 93,3 $\pm 1,1-$ $21(61,8 \%) ; 87,5 \pm 3,2-8(23,5 \%) ; 76,31 \pm 1,3-5(14,7 \%)$.

Ключові слова: шийка стегнової кістки, переломи, остеосинтез.

Surgical tactic in femoral neck fractures in young adults

Kanziuba A.I., Kanziuba M.A., Kovalchuk D.J.

${ }^{1}$ Uzhhorod National University, Uzhhorod; ${ }^{2}$ Donetsk National Medical University, Lyman; ${ }^{3}$ National Medical University O.O. Bogomolets, Kyiv

Under the age of 60, femoral neck fractures (FNF) account for 2 to $6 \%$ of all hip fractures and, in the most cases, are the result of high energy exposure. The priority of surgical tactics optimization is timprovement of osteosynthesis based on clinical and biomechanical studies, choice of fixators and justificated parameters their use. There is analysis of internal fixation of femoral neck fractures for forty-two patients with a mean age of $42,3 \pm 1,1$ years (the average $-42,3 \pm 1,1$ y.o.) that were treated between 2013 and 2019. The chois of construction and parameters of osteosyntesis are based on stress strain state (SSS) of proximal femoral bone. The results of treatment in period of 3.5 to 6 years in 34 patients by Harris Hip Score: $93,3 \pm 1,1-21(61,8 \%) ; 87,5 \pm 3,2-8(23,5 \%) ; 76,31 \pm 1,3-5(14,7 \%)$.

Key words: femoral neck, fractures, osteosynthesis.

Вступ У віці до 60 років переломи шийки стегнової кістки (ПШСК) складають від 2 до $6 \%$ від усіх переломів у ділянці кульшового суглоба i, в більшості випадків, є наслідком високоенергетичного впливу. Механогенез травми обумовлює наявність у постраждалих множинних і поєднаних пошкоджень, що ускладнює діагностику і раннє виконання остеосинтезу переломів шийки $[1,2,3]$.

Основним методом лікування ПШСК у молодому віці $є$ ретельна репозиція перелому i внутрішній остеосинтез. Разом із тим, навіть при сучасному рівні розвитку технології внутрішнього остеосинтезу ПШБК відзначається значна частота ускладнень: незрощення переломів - 10-30\%, розвиток аваскулярного некрозу головки $-10-40 \%[4,5]$.

Фактори, що визначають результат травми і результати остеосинтезу, різноманітні. Один з напрямків оптимізації хірургічної тактики є вдосконалення остеосинтезу на підставі клінічних та біомеханічних досліджень, присвячених вибору конструкції фіксаторів та обгрунтуванню параметрів їх введення у проксимальний відділ стегнової кістки.

Мета дослідження: проаналізувати клінічне застосування внутрішнього остеосинтезу при переломах ШСК в осіб молодого віку.
Матеріали та методи. Узагальнено досвід застосування внутрішнього остеосинтезу при ПШСК у період з 2013 по 2019 рр. у 42 пацієнтів (26 чоловіків і 16 жінок) у віці від 18 до 58 років (середній вік $-42,3 \pm 1,1$ року). 7 (16,7\%) отримали травму при падінні на стегно під час ходьби, 12 (28,6\%) в результаті ДТП, $23(54,7 \%)$ - в результаті падіння 3 висоти. $29(69,1 \%)$ постраждалих унаслідок високоенергетичної травми мали множинні і поєднані ушкодження. У $9(21,4)$ випадках спостерігався травматичний шок різного ступеня тяжкості. Трансцервікальні переломи були у 18 (42,9\%), базальні - у $24(57,1 \%)$. У 7 пацієнтів мали місце іпсилатеральні (односторонні) переломи шийки i діафізу стегнової кістки.

ПШСК без зміщення (I і II тип за Garden) спостерігалися у $14(33,3 \%)$ пацієнтів. У 28 $(66,7 \%)$ переломи відповідали III i IV типам. Відповідно до класифікації Pauwels у 6 пацієнтів переломи відповідали II, у решти 36 - III типу. При переломах зі зміщенням фрагментів (III та IV типи за Garden) задля визначення ступеня руйнування задньої стінки шийки виконували рентгенографію у аксіальній проекції або СКТ кульшових суглобів. 
У 3 пацієнтів остеосинтез ШСК виконаний протягом першої доби, у 29 - в період від 1 до 7 діб, у 10 - від 7 до 16 діб після травми.

Теоретичною передумовою до обгрунтування техніки остеосинтезу стали результати чисельного аналізу напружено-деформованого стану (НДС) проведеного на кінцево-елементній моделі проксимального відділу стегнової кістки. За результатами отриманих розрахунків були визначені концептуальні положення внутрішнього остеосинтезу ПШСК.

Для внутрішнього остеосинтезу застосовували конструкції, що забезпечують можливість динамічної компресії між ними, з урахуванням анатомофізіологічних особливостей проксимального відділу стегнової кістки. Це окремі гвинти (sliding screw - ковзаючий гвинт) або кутові гвинтові фіксатори (angular screw fixations) - екстракортикальні (DHS) і цефаломедулярні (PFN, Reconstructive nail).

Вибір конструкції та параметри остеосинтезу визначали на основі даних рентгенографії пошкодженого кульшового суглоба у прямій та аксіальній проекціях 3 урахуванням результатів дослідження НДС [6].

Результати досліджень та їх обговорення. Віддалені результати лікування були досліджені у 34 пацієнтів у терміни від 3,5 до 6 років. Функціональні результати (Harris Hip Score): 93,3 $\pm 1,1-$ $21(61,8 \%) ; 87,5 \pm 3,2-8(23,5 \%) ; 76,31 \pm 1,3-$ $5(14,7 \%)$

У всіх пацієнтів досягнута консолідація переломів шийки. Після виконання остеосинтезу шийки, у комплексному відновлювальному лікуванні ми вважаємо значущим тривале функціональне розвантаження пошкодженого кульшового суглоба. Залежно від типу перелома шийки стегнової кістки, особливостей застосованого остеосинтезу i характеру пошкоджень у постраждалих 3 політравмою, відновлення опороздатності оперованної кінцівки відбувалось у терміни від 6 до 9 місяців. У всіх випадках були відновлені анатомічні параметри прокисмального відділу стегнової кістки. У 7 пацієнтів відмічено клінічно значущі прояви післятравматичного дегенеративного процесу у пошкодженому кульшовому суглобі, що призвело до обмеження функції опори та ходи. За даними магнітно резонансної томографії у 4 пацієнтів зміни структури головки свідчили про прогресування аваскулярного некрозу головки. У 8 пацієнтів при контрольних обстеженнях на рентгенограмах виявлено зміни, що відповідали I-II стадії деструктивно-дистрофічного процесу. Суб'єктивно пацієнти не відзначали істотних проблем. Больовий синдром був не постійним і не вираженим. Контрактура кульшового суглоба проявлялася, головним чином, зменшенням амплітуди ротаційних рухів.

Операцію остеосинтезу ШСК виконували в положенні пацієнта на спині або на здоровому боці.
Застосовували латеральний хірургічний доступ 3 подальшою передньою артротомією для виконання відкритої репозиції фрагментів. За даними літератури, саме передня артротомія, суттєво не впливає на подальше відновлення васкуляризації шийки та головки. Певною перевагою відкритого остеосинтезу вважається можливість досягнення якісної репозиції кісткових фрагментів [7]. При переломах без зміщення, у 9 з 14 випадків, остеосинтез виконаний без оголення ділянки перелому. При застосуванні «закритого» остеосинтезу, після фіксації фрагментів, під рентгенівським контролем виконували передню капсулотомію задля забезпечення внутрішньосуглобової декомпресії. Напрямок і глибину введення фіксаторів в шийку і головку контролювали шляхом інтраопераційної рентгенографії або за допомогою ЕОПа. При застосуванні канюльваних гвинтів застосовували направляючий засіб, що забезпечував паралельність гвинтів, оптимальне їх розташування поблизу кортикального шару шийки і головне - напрямок введення відповідно до кута Pauwels.

Конструктивною особливістю застосованих фіксаторів $\epsilon$ те, що гвинтова частина фіксатора вводиться в центральний фрагмент проксимальніше лінії перелому. При цьому основа гвинта в підвертлюговій ділянці залишається рухомою відносно дистального фрагмента. Біомеханічним результатом такої фіксації є ефект ковзання (sliding). При неминучій резорбції кісткової тканини в зоні перелому, контакт між фрагментами не порушується завдяки тому, що фізіологічні навантаження, що діють на проксимальний відділ стегнової кістки в ділянці перелому, перетворюються у напруження міжфрагментарної компресії [1].

Вибір фіксаторів і параметрів їх введення в проксимальний відділ стегнової кістки здійснювали на підставі результатів чисельного аналізу напружено-деформованого стану (НДС) імплантів та навколишньої кісткової тканини. Критеріями біомеханічної оцінки обрані стабільність фіксації фрагментів (за клінічними ознаками) і максимальні значення внутрішніх напружень (напруження Мізеса), близькі до гранично припустимих для кісткової тканини.

Остеосинтез трансцервікальних переломів виконували двома або трьома канюльованими гвинтами. Напрямок введення гвинтів залежав від типу перелому за Pauwels. Згідно з результатами чисельного аналізу, при II типі гвинти вводили перпендикулярно площині перелому, при III типі - паралельно осі шийки. Введення гвинтів у головку проксимальніше ії центру, але до проникнення в субхондральний шар, виключає появу в навколишній кістковій тканині напружень, близьких до критичних, що можуть спричинити деструкцію кісткової тканини.

При трансцервікальних переломах без зміщення остеосинтез виконували двома паралельними гвинтами, що вводяться у вертикальній площині 
вздовж нижньої і верхньої кортикальної стінки шийки. Згідно з чисельними аналізами, основну фіксуючу функцію виконує дистальний гвинт, перешкоджаючи варусному зміщенню головки. Ми прагнули вводити його по дотичній і максимально близько до дуги Адамса. Функція проксимального гвинта - запобігання ротаційного компонента зміщення. Два гвинти використовували і при ПШСК незалежно від ступеня зміщенням фрагментів за Garden, за відсутності руйнування задньої стінки шийки.

Згідно з розрахунковими даними, оптимальний рівень напруженого стану в кістковій тканині і максимальну стабільність фіксації забезпечує введення в головку та шийку 3 паралельних гвинтів, які в поперечному перетині шийки утворюють фігуру трикутника 3 верхівкою, направленою до нижньої кортикальної стінки шийки. Застосування такого варіанта фіксації ми вважаємо особливо доречним при трансцервікальних переломах 3 осколковим характером руйнування задньої стінки шийки. За даними біомеханічних досліджень, два гвинти розташовані проксимально, перешкоджають зміщенню фрагментів по ширині і ротаційним зміщенням.

Оптимальні значення напружень Мізеса у середній частині гвинтів і в навколишній кістковій тканині на рівні перелому спостерігаються за умови, що гвинти розташовані поблизу кортикального шару шийки. Зменшення простору між гвинтами i, особливо, перехресне їх розташування в ділянці перелому, сприяє появі зон концентрацій напружень не тільки в гвинтах, але і в кісткових фрагментах на рівні перелому. Рівень напружень у ділянці їх концентрації можуть зумовити дистрофічні зміни в кістковій тканині і порушення репаративного процесу.

При базальних (базіцервікальних) переломах ШСК площина перелому розташовувалася, практично, вертикально. При цьому, в більшості випадків нижня межа перелому розташовувалася поблизу міжвертлюгової ділянки. Моделювання остеосинтезу для умови одноопорного стояння показало, що в медіальній стінці шийки і дистальніше зони перелому, виникає досить велика зона концентрації напружень, близьких до гранично допустимих для кортикальної кістки. Дослідження також показали, що застосування так званих «кутових» конструкцій, базова частина яких фіксується гвинтами до зовнішньої кортикальної стінки в підвертлюговій ділянці (DHS) або ітрамедулярно шляхом блокування (PFN), забезпечують значне зниження напруженого стану в кістці за рахунок розподілу навантаження вздовж металевої конструкції

Це стало підставою до використання зазначених конструкцій для остеосинтезу базальних переломів шийки. При малих анатомічних розмірах проксимального відділу стегнової кістки, а також при поширенні перелому на міжвертлюгову ділян- ку, ми вважаємо більш доцільним інтрамедулярний остеосинтез конструкції PFN. Конструкції DHS були састосовані при базальних переломах без зміщення фрагментів.

У 7 постраждалих унаслідок високоенергетичної травми (кататравма або дорожно-транспортна пригода) мали місце іпсілатеральні переломи шийки та діафізу стегнової кістки. При цьому переломи шийки мали базіцервікальну локалізацію та належали до III типу за Pauwels. У 3 постраждалих переломи шийки відповідали II, а у 4 - III-IV типап за класифікацією Garden. Особливості остеосинтезу - термін хірургічного втручання, положення пацієнта на операційному столі, вибір способу фіксації та послідовність виконання остеосинтезу діафізу і шийки стегнової кістки, залежали від загального стану пацієнта у зв'язку з множинним характером травми, характеру зміщення перелому шийки, локалізації та типу перелому діафізу [8].

Клінічне спостереження. Пацієнтка В., 40 років. Унаслідок падіння 3 балкону 4-го поверху отримала важку поєднану травму. Клінічний діагноз: закрита черепно-мозкова травма; струс головного мозку, закрита травма грудної клітки - перелом 5-8-го ребер ліворуч по задній аксілярній лінії; закритий перелом обох гілок правої лобкової кістки, перелом бокової маси крижа ліворуч; відкритий, II тип за Gustilio R.B. \&Anderson J.T. (1976) [9] лівої стегнової кістки на рівні середньої третини діафізу, базальний перелом шийки лівої стегнової кістки - III тип за Pauwels зі зміщенням - IV тип за Garden (рис. 1a); травматичний шок III ступеня. Одночасно з протишоковою терапією виконано первинну хірургічну обробку рани лівого стегна, стабілізацію переломів стегна і тазу апаратами зовнішньої фіксації.

Через 15 діб після травми виконано відкриту репозицію та інтрамедулярний остеосинтез діафізаного перелому стегнової кістки цефаломедулярним стрижнем. Під контролем ЕОПу виконана відкрита репозиція і остеосинтез базального перелому шийки стегнової кістки (рис. 1а). Післяопераційних ускладнень не було. Через 6 тижнів після травми відновлена хода за допомогою милиць без опори на пошкоджену кінцівку. Продовжувалися реабілітаційні заходи. Повне навантаження кінцівки дозволено через 6 місяців після операції остеосинтезу.

При повторному обстеженні через рік після хірургічного втручання скарг не пред'являє. На контрольних рентгенограмах виявлена консолідація переломів діафізу та шийки стегнової кістки. Контури та структура головки стегнової кістки не змінені, суглобова щілина не звужена (рис. 1б). Хода самостійна, кульгавість не спостерігається. Об'єм пасивних рухів у лівому кульшовому суглобі у сагітальній площині $-0^{\circ}-0^{\circ}-70^{\circ}$, у фронтальній $-40^{\circ}-0^{\circ}-20^{\circ}$, ротаційні рухи $-35^{\circ}-0^{\circ}-15^{\circ}$ (рис. 1в). Функціональний результат за Harris Yip Score оцінений у 94,3 бала. 


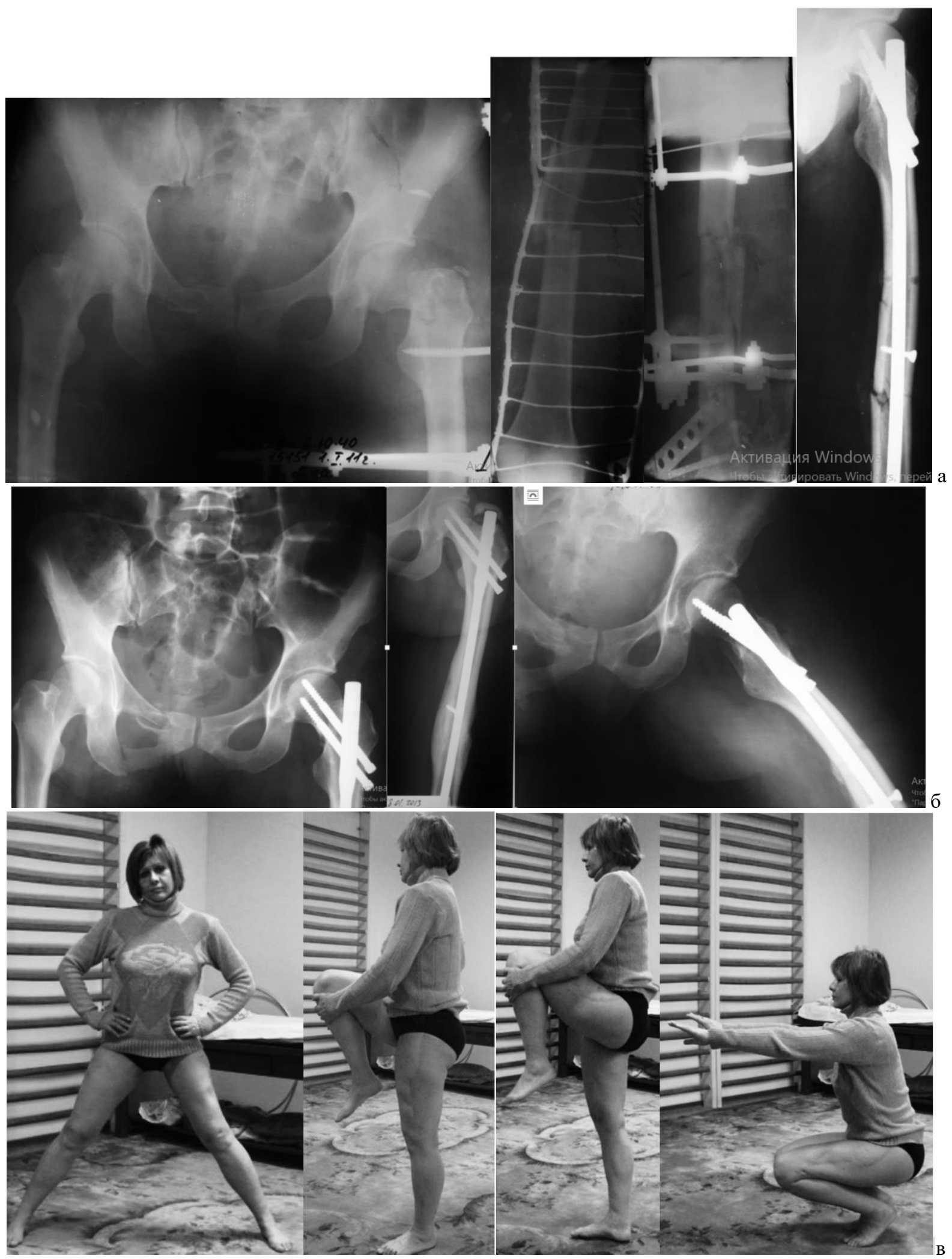

Рис. 1. Пацієнтка В., 40 років (пояснення у тексті): а - фотовідбитки рентгенограм тазу та лівого стегна при поступленні в клініку і після остеосинтезу лівої стегнової кістки; б - фотовідбитки рентгенограм тазу та лівого стегна через рік після травми; в - функціональний результат через один рік після травми. 
У 3 випадках за відсутності зміщення фрагментів у ділянці шийки, виконана роздільна фіксація проксимального метафіза конструкцією DHS i остеосинтез діафіза накістковою пластиною.

У 4 пацієнтів через необхідність виконання відкритої репозиції іпсілатерального перелому шийки і діафіза стегнової кістки виконано інтрамедулярний остеосинтез обох переломів реконструктивним цвяхом. На нашу думку, виконання репозиції перелому шийки значно полегшується після інтрамедулярної фіксації діафізарного перелому. При цьому дистальне блокування інтрамедулярного фіксатора виконується після завершення стабілізації перелому шийки.

Таким чином, при ПШСК у пацієнтів молодого віку обгрунтоване і диференційоване застосування остеосинтезу дозволяе відновити опорну і рухову функцію пошкодженої кінцівки. Загальний фізичний стан пацієнта та достатня мінеральна щільність кісткової тканини $є$ важливими чинникам, що за умов своєчасного та адекватно виконаного остеосинтезу можуть забезпечити сприятливий перебіг репаративного процесу. Визначальними для досягнення консолідації перелому шийки та сприятливого перебігу репаративнних змін у головці стегнової кістки, $\epsilon$ точна репозиція фрагментів, біомеханічно обгрунтоване виконання остеосинте- зу і тривале розвантаження кульшового суглоба у періоді реабілітації. Навіть при вимушеному відтермінуванні хірургічного втручання у постраждалих 3 політравмою, остеосинтез шийки стегнової кістки, у більшості випадків, забезпечує добрі і тривалі анатомічні та функціональні результати.

Висновки. 1. У пацієнтів молодого віку ПШСК у більшості випадків $є$ результатом високоенергетичного травматичного впливу.

2. При ПШСК у пацієнтів молодого віку внутрішній остеосинтез дозволяє відновити функцію ушкодженого кульшового суглоба.

3. При плануванні та виконанні внутрішнього остеосинтезу необхідно враховувати анатомофізіологічні особливості проксимального відділу стегнової кістки, локалізацію та тип перелому шийки за Pauwels.

4. Застосування відкритого остеосинтезу сприяє більш точній репозиції фрагментів і може пропонуватися при уламкових та зі зміщенням (Garden III - IV) переломах шийки стегнової кістки.

5. При застосуванні закритої репозиції, підчас остеосинтезу перелому шийки стегнової кістки передня капсулотомія забезпечує декомпресію кульшового суглоба і сприяє відновленню його кровозабезпечення.

\section{Список використаної літератури}

1. Duckworth A.D., Bennet S.J., Aderinto J., Keating J.F. (2011) [Fixation of intracapsular fractures of the femoral neck in young patients Risk factors for failure]. Journal of Bone and Joint Surgery, vol. 93-B, pp. 811-816. 2. Haidukewych G.J., Rothwell W.S., Jacofsky D.J., Torchia M.E., Berry D.J. (2004) [Operative treatment of femoral neck fractures in patients between the ages of fifteen and fifty years]. Journal of Bone and Joint Surgery, vol. 86-A, pp. 1711-1716.

3. Upadhyay A., Jain P., Mishra P., Maini L., Gautun V.K., Dhaon B.K. (2004) [Delayed internal fixation of fractures of the neck of the femur in young adults. A prospective, randomised study comparing closed and open reduction]. Journal of Bone and Joint Surgery, vol. 86-B, pp. 1035-1040.

4. Liporace F., Gaines R., Collinge C., Haidukewych G.J. (2008) [Results of Internal Fixation of Pauwels Type3 Vertical Femoral Neck]. Journal of Bone and Joint Surgery, vol. 90-A, pp. 1654-1659.

5. Slobogean G.P., Sprague S.A., Scott T., Bhandari M. (2015) [Complications following young femoral neck fractures]. J. Care Injured, vol. 46, pp. 484-491.

6. Klimovitskiy V.G., Kanzyuba M.A., Kanzyuba A.I. (2013) Analiz napryazhenno-deformirovannogo sostoyaniya proksimal'nogo otdela bedrennoy kosti pri vnutrennem osteosinteze po povodu perelomov sheyki [Analysis of the stress-strain state of the proximal femur during internal osteosynthesis for fractures of the neck]. Trauma, no. 2, vol. 14, pp. 30-35.

7. Kestel D., Bernstein M. (2020) [Open reduction internal Fixation of Femoral Neck Fracture - Anterior Approach]. Orthop Trauma, vol. 34, no. 8, pp. 27-28.

8. Kanzyuba A.I., Kanzyuba M.A., Chaplinskiy V.P. (2014) Ipsilateral'nye perelomy sheyki i diafiza bedrennoy kosti: khirurgicheskaya tatktika [Ipsilateral fractures of the femoral neck and diaphysis: surgical tactics]. Травма, vol. 15 , no. 2, pp. 104-107.

9. Gustilo RB, Anderson JT. (1976) [Prevention of infection in the treatment of one thousand and twenty-five open fractures of long bones: retrospective and prospective analyses]. J Bone Joint Surg Am., vol. 58, pp. 453458.

Стаття надійшла до редакції: 15.10 .2020 р. 